\section{House of Representatives Establishes Office of the Historian}

Page Putnam Miller

National Coordinating Committee for the Promotion of History (NCCPH)

On January 3 the House adopted rule changes that established the Office of the Historian. In 1982 the House passed a resolution that created an Office for the Bicentennial of the House of Representatives. Dr. Raymond Smock, an historian, headed the office and provided able leadership. Since that legislation focused on the 200 th anniversary of the House and would expire on September 30, 1989, the House has voted to establish a permanent Office of the Historian. The permanent office will ensure that the history and development of the House is given proper attention, and that House historical information is readily available. Representative Lindy Boggs (D-LA) and Representative Martin Frost (D-TX) played key roles in securing passage of the rule to establish a perma. nent historical office.

During the last five years, the Office of the Bicentennial, now the Office of the Historian, has conducted a national survey to locate the historical papers of former members of the House and has just published their findings in A Guide to Research Collections of Former Members of the House. This extremely useful research guide is available in the Federal Depository Libraries. If you wish to obtain a copy contact: Office of the Historian, U.S. House of Representatives, Cannon House Office Building, Room 138, Washington, DC 20515.

\section{Federal Suit To \\ Prevent Destruction of White House Computer Tapes}

Page Putnam Miller

$\mathrm{NCCPH}$

Journalist and author Scott Armstrong and former U.S. Senator Gaylord Nelson, with other plaintiffs, filed suit on January 19 against President Reagan, President-elect Bush, and the Archivist of the United States to prevent the destruction of secret National Security Council internal computer messages, commonly known as PROFS (Professional Office System, originated by (BM). The National Archives' position has been that most of the items on the electronic tapes were brief messages, equivalent to telephone slips, and that substantive statements or memos of permanent value were printed out and preserved in paper form. However, Armstrong said the Iran-Contra affair demonstrated that many important messages existed only on tape. In response to the suit, the White House has stressed that there was nothing improper about the destruction of the electronic tapes because leaving the National Security Council computer system clogged with Reagan administration data would be a handicap to the new administration. The restraining order to prevent the destruction of the electronic records was originally to expire on January 30 . However the judge extended the time and heard the case on March 15. A decision is expected soon. Members of both the Senate and the House have expressed concern about this matter for it raises larger issues about the authority of the Archivist and federal policies for dealing with electronic records. 